\title{
Elemental Analysis of Rice Husk Using X-Ray Fluorescence Techniques - A Case Study of Jigawa State, Nigeria.
}

\author{
${ }^{*}$ G. D Adamu ${ }^{1}$, H. Y Shuaibu ${ }^{1}$, M. N Maharaz ${ }^{1}$, E. N Chifu ${ }^{1}$, N. W Silikwa ${ }^{2}$, \\ F. M Lariski ${ }^{3}$, S. S Zarma ${ }^{1}$, U M Dankawu ${ }^{1}$ and J. N Benedict ${ }^{1}$ \\ ${ }^{1}$ Department of Physics \\ Federal University Dutse, \\ P.M.B 7156, Jigawa State, Nigeria. \\ ${ }^{2}$ Department of Physics \\ Adamawa State University \\ Mubi, Adamawa State, Nigeria. \\ ${ }^{3}$ Department of Physics \\ Yobe State University, \\ Damaturu, Nigeria.
}

Email: adamugaima@gmail.com

\begin{abstract}
The rice husk or hard protective shell are woody, siliceous, and not edible part of the rice plant. Here in, the elemental composition of rice husk was determined using the energy dispersive X-ray Fluorescence Technique. The rice husks were obtained from four different Local Governments namely, Hadejia, Dutse, Auyo and Ringim of Jigawa State, Nigeria. The samples were collected during dry season and ground into a fine powder using mortar and pestle The results of the analyses revealed the presence of eleven elements which are; Silicon (Si), Rubidium (Rb), Potassium (K), Calcium (Ca), Manganese (Mn), Iron (Fe), Nickel (Ni), Copper (Cu), Zinc ( $\mathrm{Zn})$, Bromine (Br) and Strontium (Sr) for Hadejia and Ringim while Dutse and Auyo are having ten with the absence of Br. The elements detected and their concentration (in \%) for Hadejia, Dutse, Auyo and Ringim respectively are as follows Si (69.05, 70.52, 73.18, 69.33), Rb (0.321, 0.153, 0.164, 0.219), K (16.52, 16.03, 14.29, 16.66), $\mathrm{Ca}(8.45,8.064,8.101,8.85), \mathrm{Mn}(1.104,1.026,0.99,1.077), \mathrm{Fe}(3.739,3.564,2.719,3.162)$, Ni $(0.27,0.291,0.291,0.249,0.26), C u(0.021,0.018,0.017,0.015), Z n(0.36,0.266,0.226,0.307)$, $\operatorname{Br}(0.065,0.00,0.00,0.046)$ and $\operatorname{Sr}(0.087,0.056,0.05,0.063)$. The results of the analysis in \% shows Si with high percentage concentration followed by $K$ and the rest are in the following ascending order $\mathrm{Ca}>\mathrm{Fe}>\mathrm{Zn}>\mathrm{R} b>\mathrm{Sr}>\mathrm{Br}>\mathrm{Ni}>\mathrm{Cu}$. Four new elements were discovered namely; $\mathrm{R} b, \mathrm{Cu}$, $\mathrm{Sr}$ and $\mathrm{Br}$ in rice husk which were not common in other existing studies. The composition can also be affected by factors such as soil chemistry, climatic conditions, and the type of fertilizer used.
\end{abstract}

Keywords: XRF Technique, Rice husk, Elemental Composition, Silicon

\section{INTRODUCTION}

Rice husk (RH) is the major pollutant in rice milling environment which it contain the outer hard protective shell which surrounds the paddy grain and accounts for $20 \%$ of its weight. 
Many researchers investigated the applications of rice husks as product in various industries. The husk mostly removed during rice milling out of which about $20 \%$ of the weight of paddy received as husk. It is designed from hard materials, including opaline silica and lignin (Alfaro et al., 2013). It has been used as constituent in building material, fertilizer, insulation material, or fuel (Navin, 2021). Rice husks which is obtain from rice paddy, having the hard protective coverings of rice grains which are separated from the grains during milling process. Rice husk are the most abundantly available waste material that the society neglect it contains about $30 \%-50 \%$ of organic carbon. In the course of a typical milling process, the husks are removed from the raw grain to reveal whole brown rice which upon further milling to remove the bran layer will yield white rice. Current rice production in the world is estimated to be 700 million tons. Rice husk constitutes about $20 \%$ of the weight of rice and its composition is as follows: cellulose (50\%), lignin $(25 \%-30 \%)$, silica $(15 \%-20 \%)$, and moisture $(10 \%-15 \%)$. Bulk density of rice husk is low and lies in the range $90-150 \mathrm{~kg} / \mathrm{m}^{3}$ (Singh, 2018). From all indication it shows that, the production of rice will continue increasing day by day. $20 \%$ of rice paddy is the husk which is considered to be waste and the issue of disposing it is not properly addressed. Unfortunately we always discharge it into sea and ocean or burning it in an open air, these will also lead to the increase in pollution (Singh, 2018).

The need for energy and its related services to satisfy human need; social and economic development, welfare and health is increasing (Owusu \& Asumadu-Sarkodie, (2016). Energy development is closely linked with the economic development of a country. The issue of disposing the rice husk after dehusking is one of the major challenge in the country. This can be minimize by determining it constituent like the elemental components. Creating a channel that will enlighten the society to know it economic importance like this study, will go a long way to the development of Northern Nigeria and the country at large. Rice husk found to be useful in industries which include optical and radiation shielding properties (Tuscharoen et al., 2012), in concrete (Singh, 2019) in production of ceramic and refractory industry (Bhavana, 2016), in power generation (Oti 2020), electrical energy potential as fuel for power generation (Muhammad, 2015) and Electricity production potential.

The existing research that analyzed elemental composition of rice husk in Nigeria, to the best of my knowledge is that of Kogi which was carried out by (Omatola, 2009) and that of Abakaliki conducted by Igwebike-Ossi, (2017). The novelty of the finding are; the first elemental analysis of rice husk to be carried out in Jigawa State, The findings does not cover the entire Jigawa State but four Local Government only, which are; Hadejia, Auyo, Ringim and Dutse. XRF technique and Global Positional System (GPS) were used in elemental composition and determination of positions respectively. Analysis was done using the standard method which is $80 \%$ Accuracy as compared with standard less method of $50 \%$ Accuracy the standard method is totally depended on calibration curve of each element. Once the calibration curve of the elements is good, the results will also be good the standard method were form by standard reference material obtained from International Atomic Energy (IAEA) providing certificate of analysis for powder Biological samples while the standard less were calibration from factory. The analytical problems in a quantitative determination of low atomic number elements originate from the inherent performance caused by the low excitation efficiency of soft X-rays and low reflectivity of spectroscopic device (Beckhoff et al., 2006).

Government intervention in rice has leaned towards providing input such as improved seedlings and fertilizer to small holder farmers. In addition, through the Central Bank of Nigeria, funding has been made available to rice farmers at affordable rates through the 
Anchors Borrower's Programed. With such motivation from Government, it will lead to increase in rice husk production (Emefiele, 2021). Research of this kind will go a long way in providing alternative use of rice husk as raw material in terms of production rather than burning it in to an open air. Moreover, suitability of rice husk to be used for different application depends upon the chemical properties of the husk such as ash content, silica content etc.

\section{MATERIALS AND METHODS}

\section{Study Area}

The study area is in Northern Nigeria, Jigawa State. The study area falls between $12^{\circ} 05^{\prime} 60^{\prime \prime} \mathrm{N}$ and $09^{\circ} 33^{\prime} 36^{\prime \prime} \mathrm{E}$ with an estimated area of $23,154 \mathrm{~km}^{2}$. With some selected regions within the State which include Hadejia, Auyo, Dutse and Ringim. The selection is based on the proximity and the nature of the terrain which is good for rice farming. The area where samples were collected include four Local Governments. With Hadejia the highest rice cultivating Local Government amongst the four location, Federal Government empowerment simplify rice farming in the area. The study area, in wet season is muggy and mostly cloudy, the dry season is partly cloudy, and it is hot year round. Over the course of the year, the temperature typically varies from $21^{\circ} \mathrm{C}$ and $32^{\circ} \mathrm{C}$.

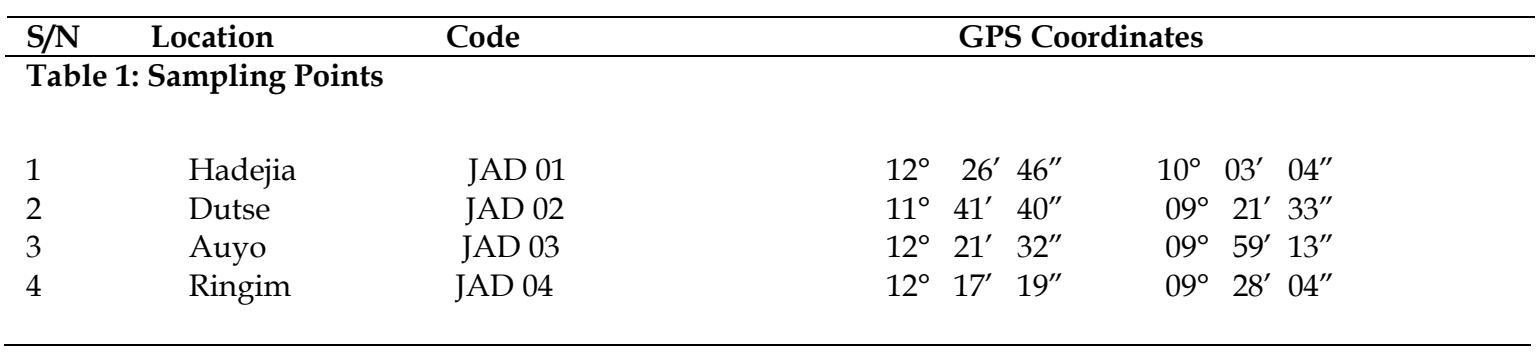

Table 1 shows the code of each sample was represented by the letter $\mathrm{J}$ with the addition of two letters AD and serial number from one to four.

\section{Method of Sample Collection}

In this study, the samples were collected during dry season between the period of $5^{\text {th }}$ December 2020 to 15th December 2020. Almost all the samples were collected in the milling site close to the farm area where they are planted. Global Positioning System was used in taking the point or location were each samples were collected. Rubber containers were used in collecting the samples and masking tape in labelling each sample. Places where the samples were collected are Hadejia, Dutse, Auyo and Ringim.

\section{Method of Sample Preparation}

The rice husk were first ground to a fine powder with the aid of mortar and pestle. $2 \mathrm{~g}$ of each of the samples were weighed and then poured into a sample holder and covered with cotton wool to prevent it from spraying. The bottom of the samples holder is made of polypropylene which is a thermoplastic. The sample holders containing the sample which were run in a vacuum or air for 10 minutes and they were inserted into the XRF Spectrometer for the Elemental analysis. 


\section{Method of Data Analysis}

This involve the computation of result obtained which is more of conversion and calculation of percentage elements in a sample. The XRF concentration values of the elements generated in parts per million (ppm) were converted to percentage (\%) concentration as follows: (Alvord, 2020)

$$
\begin{aligned}
1 \mathrm{ppm} & =\frac{1}{1000000} \\
\mathrm{in} \% & =\frac{1}{1000000} \times 100=\frac{1}{10000}
\end{aligned}
$$

To convert $x p p m, x \%=\frac{x p p m}{10000}$

According to Odesina (2008), the mass \% is geven as;

$$
\text { Mass percentage }=\frac{\text { mass of solute }}{\text { mass of solution }} \times 100 \%
$$

\section{RESULTS}

Table 2. Shows the percentage elements that are present in four selected Local Government of Jigawa State Indicating the absence of Bromine in Dutse and Auyo.

Table 2: Elemental components (in \%) of Rice Husk in Four Selected Local Government Areas of Jigawa State.

\begin{tabular}{cccccc}
\hline Elements & JAD 01 & JAD 02 & JAD 03 & JAD 04 & Mean \\
\hline $\mathrm{Si}$ & 69.05 & 70.52 & 73.18 & 69.33 & 70.52 \\
$\mathrm{Rb}$ & 0.32 & 0.15 & 0.16 & 0.22 & 0.21 \\
$\mathrm{~K}$ & 16.52 & 16.03 & 14.29 & 16.66 & 15.88 \\
$\mathrm{Ca}$ & 8.45 & 8.06 & 8.10 & 8.85 & 8.35 \\
$\mathrm{Mn}$ & 1.10 & 1.03 & 0.99 & 1.08 & 1.05 \\
$\mathrm{Fe}$ & 3.74 & 3.56 & 2.72 & 3.16 & 3.30 \\
$\mathrm{Ni}$ & 0.27 & 0.29 & 0.25 & 0.26 & 0.27 \\
$\mathrm{Cu}$ & 0.021 & 0.02 & 0.02 & 0.02 & 0.02 \\
$\mathrm{Zn}$ & 0.36 & 0.27 & 0.23 & 0.31 & 0.28 \\
$\mathrm{Br}$ & 0.07 & - & - & 0.05 & 0.03 \\
$\mathrm{Sr}$ & 0.09 & 0.06 & 0.05 & 0.06 & 0.06 \\
\hline
\end{tabular}

Fig 1. Below shows the concentration of each element across the various rice husk samples 


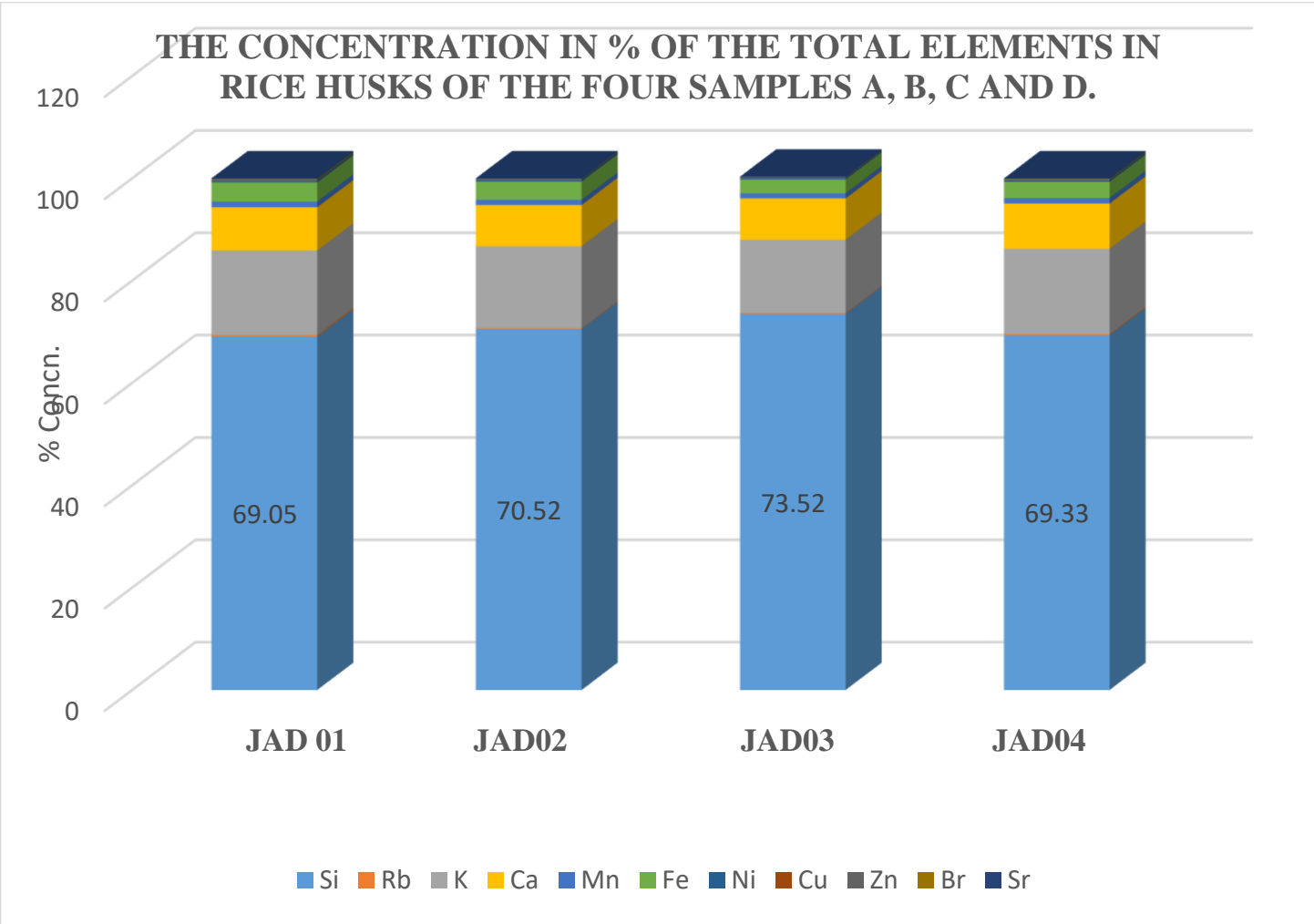

Fig 1. Elemental Conc. in Four Local Government of Jigawa State

The colour represent each element in the samples as shown in Fig 1, clearly from the colors the major elements are four namely; Silicon $(\mathrm{Si})$, Potassium $(\mathrm{K})$, Calcium $(\mathrm{Ca})$ and Iron $(\mathrm{Fe})$ represented by the colors blue, grey, yellow and green respectively. The minor elements are in fraction that is why there colors are not clear. The percentage concentration of major elements are almost close to each other with slight difference for instance the range of four major elements are; Si 69.05 to 73.18 , K 14.29 to 16.66 , Ca 8.06 to 8.85 and Fe 2.72 to 3.74. The results of the elemental analysis of rice husk sample using the XRF spectrometric technique revealed the presence of a total eleven (11) elements; Silicon (Si), Rubidium ( $\mathrm{Rb}$ ), Potassium $(\mathrm{K})$, Calcium (Ca), Manganese (Mn), Iron (Fe), Nickel (Ni), Copper (Cu), Zinc (Zn), Bromine $(\mathrm{Br})$ and Strontium (Sr), with the exception of Dutse and Auyo as shown in Table 2.

Fig 2 shows the XRF spectra of four rice husk samples

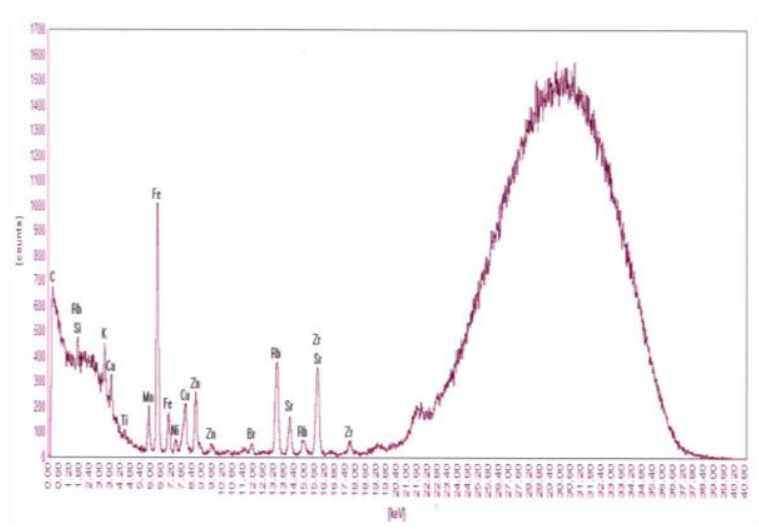

(a) JAD 01

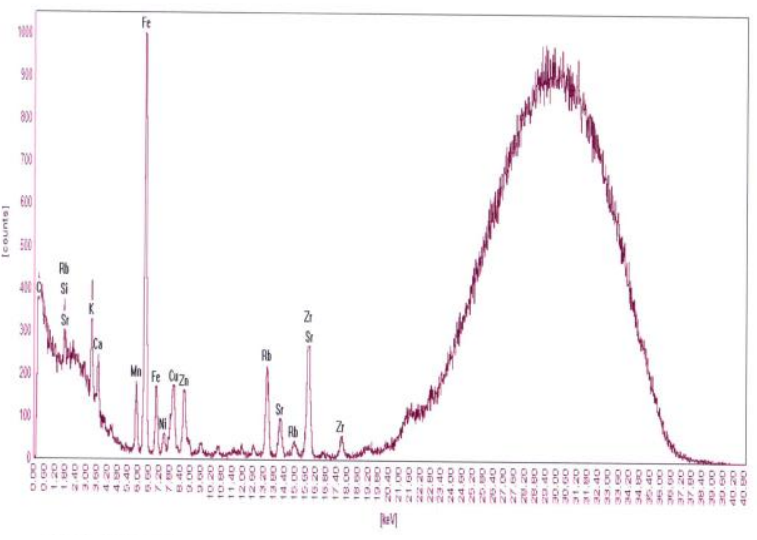

(b) JAD 02 


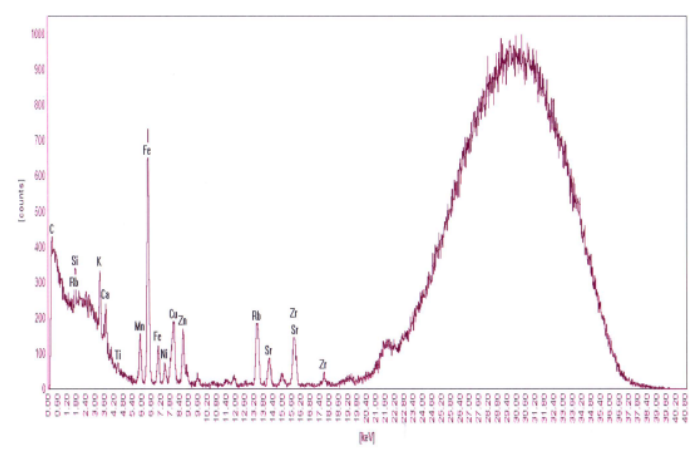

(c) JAD 03

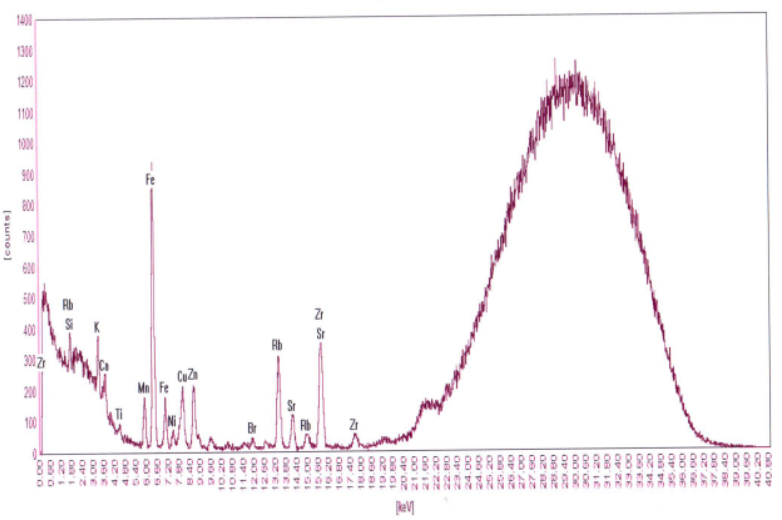

(d) JAD 03

Fig. 2: XRF Spectra for Various Rice Husk Samples

\section{DISCUSSION}

The predominant element was found to be $\mathrm{Si}$, in oxide the result obtained for mean samples in Table 2. $\mathrm{SiO}_{2}=70.52+(0.533 \times 32)=87.58 \%$ is close to some literature values Balakrishnan, (2006), Muntohar, (2002). The most common types of analyses that have been carried out to determine the chemical composition of rice husks are; proximate analysis, (Evvie Chockalingam, 2005), ultimate analysis and component analysis Ankit et al., (2019). In the XRF analysis of RHA samples obtained by burning rice husks from Benue and Kogi states of Nigeria thirteen elements (in the form of their oxides) were detected; $\mathrm{K}, \mathrm{Ca}, \mathrm{Cr}, \mathrm{Mn}$, $\mathrm{Fe}, \mathrm{Ni}, \mathrm{Cu}, \mathrm{Zn}, \mathrm{Sr}, \mathrm{Br}, \mathrm{I}, \mathrm{As}$, and $\mathrm{Cl}$, Omatola, (2009). Igwebike-Ossi (2016) reported the presence of fourteen elements in Abakaliki (in the form of their oxides) in RHA with the greater portion of the weight having $\mathrm{Si}$ (present as $\mathrm{SiO} 2$ ) using the PIXE technique. The elements reported in oxide were as follows; $\mathrm{SiO}_{2}, \mathrm{Al}_{2} \mathrm{O}_{3}, \mathrm{Fe}_{2} \mathrm{O}_{3}, \mathrm{CaO} \mathrm{MgO} \mathrm{Na} 2 \mathrm{O}, \mathrm{K}_{2} \mathrm{O}, \mathrm{P}_{2} \mathrm{O}_{5}$, $\mathrm{SO}_{3}, \mathrm{ClO}_{3}, \mathrm{TiO}_{2} \mathrm{MnO}, \mathrm{ZnO}$ and $\mathrm{Rb}_{2} \mathrm{O}$ others that are close to the findings with eleven elements using same techniques XRF are; in Egypt Alyosef et al., (2013), in Cambodia and Italy Schneider et al., (2018).

The chemical composition of different rice husk is found to be varying due to difference in climate conditions. The chemical composition of rice husks varies across the States and other studies, as it dependent on several factors and since rice husk is obtained from the rice, the composition can also be affected by these same factors which are soil chemistry, climatic conditions, paddy variety and the type of fertilizer used (Chandrasekar et al, 2003 : Omatola and Onojah, 2012). The suitability to be used for different application also depend on the elements present in the rice husk. Therefore, the finding will go a long way in providing alternative uses of rice husk rather than discharging it into revers.

In Turkey report obtained shows twelve elements in rice husk which are in oxide form; $\mathrm{SiO} 2, \mathrm{Al}_{2} \mathrm{O}_{3}, \mathrm{WO}_{3}, \mathrm{Fe}_{2} \mathrm{O}_{3}, \mathrm{MnO}, \mathrm{CaO}, \mathrm{MgO}, \mathrm{Na}_{2} \mathrm{O}, \mathrm{K}_{2} \mathrm{O}, \mathrm{SO}_{3}, \mathrm{P}_{2} \mathrm{O}_{5}$, and $\mathrm{ZnO}$, (Alvarez, 2014) in Bilbao, Spain and (Valverde, 2007) in California, USA. They reported ten elements in oxide form; $\mathrm{SiO} 2, \mathrm{Al}_{2} \mathrm{O}_{3}, \mathrm{TiO}_{2}, \mathrm{Fe}_{2} \mathrm{O}_{3}, \mathrm{CaO}, \mathrm{MgO}, \mathrm{Na}_{2} \mathrm{O}, \mathrm{K}_{2} \mathrm{O}, \mathrm{SO}_{3}$ and $\mathrm{P}_{2} \mathrm{O}_{5}$. Likewise, Alyosef et al., (2013) in Egypt reported ten elements in rice husk using XRF technique with the same numbers which are; $\mathrm{SiO} 2, \mathrm{Al}_{2} \mathrm{O}_{3}, \mathrm{Cl}, \mathrm{Fe}_{2} \mathrm{O}_{3}, \mathrm{CaO}, \mathrm{MgO}, \mathrm{Na}_{2} \mathrm{O}, \mathrm{K}_{2} \mathrm{O}, \mathrm{SO}_{3}$ and $\mathrm{P}_{2} \mathrm{O}_{5}$ with $\mathrm{Cl}$ substituting $\mathrm{TiO}_{2}$ making slight difference with that California and Bilbao. The four results found in Turkey,Spain, USA and Egypt match with that of Dutse and Auyo in Nigeria in terms of number of major element in elemental form which are; $\mathrm{Si}, \mathrm{Rb}, \mathrm{K}, \mathrm{Ca}, \mathrm{Mn}, \mathrm{Fe}, \mathrm{Ni}, \mathrm{Cu}$, $\mathrm{Zn}$ and Sr while Hadejia and Ringim are having the addition of $\mathrm{Br}$. In the other hand Schneider et al., (2018) in Cambodia and Italy, nine elements were determined in oxide form; 
$\mathrm{SiO} 2, \mathrm{Al}_{2} \mathrm{O}_{3}, \mathrm{Cl}, \mathrm{Fe}_{2} \mathrm{O}_{3}, \mathrm{CaO}, \mathrm{MgO}, \mathrm{K}_{2} \mathrm{O}, \mathrm{SO}_{3}$ and one not identify. The difference in my findings with that of the other researchers in different part of the world, are the presence of $\mathrm{Rb}, \mathrm{Cu}, \mathrm{Sr}$ and $\mathrm{Br}$ which is not common in elemental analysis of rice husk. The common similarity in all the findings is the predominant of Silicon and most of the analysis were carried out by $\mathrm{X}$-ray Fluorescence technique. Presence of four elements $\mathrm{Rb}, \mathrm{Cu}, \mathrm{Sr}$ and $\mathrm{Br}$ which are not common in other studies and the only finding that contained the four new elements is that of Kogi State, Nigeria but the researcher lay more emphasis on percentage impurities and purities not percentage concentration of element.

\section{CONCLUSION}

The elemental analysis of rice husk using X-ray Fluorescence in four Local Government of Jigawa State, Nigeria reveals the total of eleven elements with the exception of Dutse and Auyo. The findings indicate the predominant element to be silicon with slight difference between the four samples which agrees with the world standard. The performance of the $\mathrm{XRF}$ as measured by detection limits and ability to accurately quantify an element is highly variable from element to element. One of the factors contributing to variations in performance is the interference among elements whereby the elevated presence of one element may mask the elevated presence of another. Despite that the results are not far from other existing studies with addition of Four new elements were discovered namely; $\mathrm{Rb}, \mathrm{Cu}$, Sr and Br. Lastly, Jigawa State as one of the rice producing State in North West, this findings will assist in creating awareness to researchers and the inhabitant within the region to the chemical properties attach to rice husk. Presence of four elements $\mathrm{Rb}, \mathrm{Cu}, \mathrm{Sr}$ and $\mathrm{Br}$ which are not common in other studies and the only finding that contained the four new elements is that of Kogi State, Nigeria but the researcher lay more emphasis on percentage impurities and purities not percentage concentration of element.

\section{ACKNOWLEDGEMENT}

The author is immensely grateful to Engr. Abdulraham Abdulhamid of Umaru Musa Yar'adua University, Nigeria. For carrying out the analysis of rice husk using XRF technique.

\section{REFERENCES}

Alfaro, E., Dias, D., \& Silva. (2013).The study of ionizing radiation effects on polypropylene and rice husk ash composite. Radiation Physics and Chemistry, 84: 163-165.

Alosef, H., Eilert, A., Welscher, J., Ibrahim, S., Denecke, R., Schwieger, W., \& Enke, D. (2013). Characterization of Biogenic Silica Generated by Thermo Chemical Treatment of Rice Husk. Part. Sci. Technol, 31, 524-532.

Alvarez, J. L. (2014). Bio oil production from rice husk fast pyrolysis in a spouted bed reactor. Fuel, 128, 162-169

Alvord, M. (2020). ZTC Textbooks Adjunct Faculty (Environmental Control) at College of the Canyons. Calfornia : Work Force.

Balakrishnan, S. (2006). Rice Husk Ash Silica as a Support Material for Iron and Ruthenium Based Heterogeneous Catalyst. M.Sc Thesis, School of Chemical Sciences, Universiti Sains Malaysia.

Beckhoff .B, K. (2006). Handbook Practical X-ray flourescense Analises. Germany: Springer Berlin Heidelberg New York.

Chandrasekar, S. S. (2003). “Processing, properties and Applications of Reactive Silica from Rice Husk. Journal of Materials Science, ,38, p. 3159.

Emefiele, G. (3th March 2021). News Paper. This Day, 2 
Evvie Chockalingam, K. S. (2005). Rice husk filtrate as a nutrient medium for the growth of Desulfotomaculum nigrificans: characterisation and sulfate reduction studies. Journal of Biotech, 1880-1888.

Igwebike-Ossi, C. D. (2016). Elemental Analysis of Rice Husk Ash Using Proton-Induced XRay Emission Spectrometry. International Journal of Applied Chemistry, 233-242.

IJESC, (2016). Properties and Industrial Applications of Rice Husk. International Journal of Engineering Science and Computing, 2679.

Muhammad Anshar, F. N. (2015). Electrical Energy Potential Of Rice Husk As Fuel For Power Generation In Indonesia . Arpn Journal of Engineering and Applied Sciences, $1819-6608$.

Muntohar, A. (2002). Utilization of uncontrolled Burnt Rice Husk Ash in soil improvement. Dimenia Teknik Sipil, 4.2. 100-105.

Navin Chand, M. F. (2021). Natural fibers and their composites. Woodhead Publishing Series in Composites Science and Engineering, 1-59.

Odesina.A. (2008). Essential Chemistry for Senior Secondary Schools. Ogun State: Tonad Publishers Limited, 30

Omatola, K. M. (2009). Elemental analysis of rice husk ash using X - ray fluorescence technique. International Journal of Physical Sciences. 189-193.

Omatola K.M and Onojah, A. (2012). Rice Husk as A Potential Source of High Technological Raw Materials: A Review. Journal of Physical Sciences and Innovation, 2277-0119.

Oti Stephen Ejiofor, P. A. (2020). Off-grid electricity generation in Nigeria based on rice husk gasification technology. Journal of Applied Physics, .2020.100009 1-13.

Schneider, D., Wassersleben, S., Wieb, M., Denecke, R., Sterk, A., \& Enke, D. A. (2018). Generalized Procedure for the Production of High-Grade, Porous Biogenic Silica. Waste Biomass Valor, 37, 667.

Singh, A. G. (2019). A Study On Use Of Rice Husk Ash In Concrete. Engineering Heritage Journal 10.26480.01.2019.01.04.

Singh, B. (2018). Waste and Supplementary Cementitious Materials in Concrete. In R. Siddique, \& P. Cachim, Waste and supplementary cementitious materials in concrete (pp. 978-0-081056-9). England: Woodhead Publishing. Schneider, D., Wassersleben, S., Wieb, M., Denecke, R.,

Sterk, A., \& Enke, D. A. (2018). Generalized Procedure for the Production of High-Grade, Porous Biogenic Silica. Waste Biomass Valor, 37, 667.

Tusharoen S. Kaewkhao. J. Limsuwan .P and Chewpraditkul W. (2012). Structural, Optical and Radiation Shielding Properties of $\mathrm{BaO}_{-} \mathrm{B}_{2} \mathrm{O} 3-\mathrm{Rice}$ Husk Ash Glases. Env.Sci. 32 734-739

Valverde, A. S. (2007). Comparative analysis of the Fhysicochimicals characteristics of the rice husk. Scientia et Technica, 37, 255-260. 